\title{
Selective Inactivation of an Extra-cytoplasmic Acid Phosphatase of Yeast-like Cells of Sporothrix schenckii by Sodium Fluoride
}

\author{
By WILFRED N. ARNOLD, * KAZUHIKO H. SAKAI AND \\ LARRY C. MANN \\ Department of Biochemistry, University of Kansas Medical Center, \\ Kansas City, Kansas 66103, USA
}

(Received 16 September 1986; revised 14 January 1987)

\begin{abstract}
Suspensions of intact, yeast-like cells of Sporothrix schenckii exhibited an acid phosphatase (EC 3.1.3.2) activity against $p$-nitrophenyl phosphate of about $5 \mathrm{IU}(\mathrm{g} \text { dry wt })^{-1}$, without recourse to membrane perturbation. This extra-cytoplasmic acid phosphatase was reversibly and competitively inhibited by orthophosphate $\left(K_{\mathrm{i}}=2 \mathrm{mM}\right.$ at $\left.\mathrm{pH} 5\right)$ but unaffected by $\mathrm{L}(+)$ tartrate (in contradistinction to some of the cytoplasmic acid phosphatases of the same organism). Inactivation by $\mathrm{NaF}$ of the extra-cytoplasmic isoenzyme was irreversible and followed first order kinetics; sensitivity to $\mathrm{NaF}$ was decreased by the presence of citrate, phosphate or substrate. Neither $K_{\mathrm{m}}\left(0.3 \mathrm{mM}\right.$ at pH 5) nor $V_{\max }$ for this enzyme in acetate buffer was greatly affected by $\mathrm{pH}$ in the range 3-5 but the first order rate constant for inactivation by $\mathrm{NaF}$ was strongly dependent on $\mathrm{pH}$ (maximum at pH 3.5). Crude cell-free extracts of yeast cells had nine electrophoretically distinct acid phosphatase activity bands and, on the basis of the pattern of inhibitors, the extra-cytoplasmic activity was identified as Y-I, an isoenzyme that barely penetrates standard polyacrylamide gel electropherograms. Additional evidence for the assignment came from selective inactivation of this isoenzyme by short treatments of intact cells with $\mathrm{NaF}$ under conditions that did not allow penetration of the plasma membrane by the inhibitor and did not kill the cells.
\end{abstract}

\section{INTRODUCTION}

Mycelial and yeast cells of the dimorphic fungus Sporothrix schenckii both exhibit a multiplicity of cytoplasmic and extracytoplasmic sites of acid phosphatase (EC 3.1.3.2) activity (Garrison \& Arnold, 1983). The acid phosphatases are ubiquitous among yeast and yeastlike organisms (Arnold, 1981), but they are of special interest with $S$. schenckii because of differences in the isoenzyme patterns among cells of the saprophytic and pathogenic forms (Arnold et al., 1986).

S. schenckii has world-wide distribution in soil and on plants as saprophytic mycelia adorned with conidia. Subcutaneous introduction of mycelia or conidia into animals can result in sporotrichosis, due to proliferation in the host tissues of yeast-like cells that arise by transformation at the higher temperature and multiply by budding. Several reports on ultrastructure and immunochemistry (for a review see Travassos \& Lloyd, 1980) have appeared, but there has been a paucity of investigations on the enzymology of $S$. schenckii. Our recent findings on acid phosphatase isoenzymes are the first to demonstrate enzymic differences associated with dimorphism in this fungus. Different cell types of $S$. schenkii can be produced simply by regulating the growth temperature and this, together with the medical relevance, commend this organism for further studies of mycotic dimorphism.

We have reported (Arnold et al., 1986) that the nine isoenzymes of acid phosphatase in yeast cells of $S$. schenckii are inhibited to varying degrees by fluoride, L(+)-tartrate and orthophosphate. In cytochemical studies with glutaraldehyde-fixed (and concomitantly 
permeabilized) cells, the addition of $\mathrm{NaF}$ to control incubations with a modified Gomori (1950) reagent obliterated all the sites of acid phosphatase activity (Garrison \& Arnold, 1983). The generality of the inhibition did not help to discriminate the isoenzymes or the sub-cellular sites. However, we now report that the extra-cytoplasmic fraction of acid phosphatase (in intact yeast cells) can be irreversibly and selectively inactivated by low concentrations of $\mathrm{NaF}$. This observation, together with the results of other inhibition studies on intact and broken cells, and correlative electrophoretic analyses, has provided sufficient evidence to identify the isoenzyme in question.

\section{METHODS}

Organism. Sporothrix schenckii (strain 29, Institut Pasteur) was grown in liquid YNG medium, which contained yeast extract $(0.3 \%, w / v)$, neopeptone $(0.5 \%, w / v)$ and glucose $(1 \%, w / v)$, at $35^{\circ} \mathrm{C}$, and with shaking $(175$ orbits $\mathrm{min}^{-1}$ ). Flasks received a small inoculum of mycelia plus conidia (from a $3 \mathrm{~d}$ culture on $\mathrm{YNG}$ at $23^{\circ} \mathrm{C}$ ) and after $3 \mathrm{~d}$ at $35^{\circ} \mathrm{C}$ (and two orders of magnitude cell mass increase) the cultures were composed almost exclusively of yeast cells (confirmed by light and electron microscopy). Celis were harvested by centrifugation, washed once in 0.25 M-sodium acetate/acetic acid ('acetate') buffer (pH 6.5) and resuspended in the same buffer to $20 \%$ (wet wt/vol.).

Enzyme assays. One international unit (IU) of acid phosphatase is the amount of enzyme that catalyzes the hydrolysis of $1 \mu \mathrm{mol} p$-nitrophenyl phosphate $\mathrm{min}^{-1}$ at $30^{\circ} \mathrm{C}$. The standard conditions were $10 \mathrm{~mm}$-substrate in the presence of $0.2 \mathrm{M}$-acetate buffer ( $\mathrm{pH} 5.0$ ). Incubations were terminated by addition of $\mathrm{NaOH}$ (final concentration $0.4 \mathrm{M}$ ), clarified by centrifugation and assayed for nitrophenolate ion (absorbance at $425 \mathrm{~nm}$ ). Assays that involved $\mathrm{NaF}$ were done in polyethylene tubes. Specific activities are expressed on a dry wt basis; yeast concentrations were monitored turbidimetrically.

Acid phosphatase isoenzymes. Cells were broken by three passages of suspension through a French pressure cell operated at $138 \mathrm{MPa}$ and $4{ }^{\circ} \mathrm{C}$. The disrupted material was cleared by centrifugation $\left(20 \mathrm{~min}, 20200 \mathrm{~g}, 4^{\circ} \mathrm{C}\right)$, and a sample of the supernatant fraction was transferred to $20 \mathrm{mM}$-glycine/Tris, $\mathrm{pH} 7.5$, by gel permeation chromatography. Samples were then subjected to electrophoresis in a continous buffer system ( $80 \mathrm{~mm}$-glycine/ $5 \mathrm{mM}$-Tris, pH 8.0), through polyacrylamide gel $\left(7 \cdot 7 \%\right.$, w/v, total acrylamide; $2.6 \%$ crosslinker) cylinders at $4{ }^{\circ} \mathrm{C}$. Acid phosphatase activity bands were revealed by equilibrating individual gels with $0.2 \mathrm{M}$-acetate buffer (pH 5.0 ) and then incubating them with a reagent (Davis \& Ornstein, 1959) composed of $\alpha$-naphthyl phosphate and freshly diazotized pararosaniline, also at pH 5.0. Gels were subsequently washed in cold buffer followed by $7 \%(\mathrm{v} / \mathrm{v})$ acetic acid and stored in the cold. All of the above methods were described in detail by Arnold et al. (1986).

Materials. Media components were from Difco. Monomers and catalysts for casting gels were from Bio-Rad; AR grade chemicals were used throughout; $\mathrm{NaF}$ was further purified by recrystallization from distilled water and propan-2-ol (Ivett \& DeVries, 1941) in plastic-ware.

\section{RESULTS AND DISCUSSION}

\section{Extra-cytoplasmic fraction of acid phosphatase}

The amounts of enzyme found in spent media or cellular washes were less than $4 \%$ of the total so secretion by live cells was not significant. Freshly harvested and washed cells exhibited 4-6 IU $\mathrm{g}^{-1}$. In intact baker's yeast cells it is known that $p$-nitrophenyl phosphate and other phosphate esters penetrate the cell wall but are excluded from the cytoplasm by the plasma membrane (Arnold \& Lacy, 1977). Assays on untreated cell suspensions give an accurate estimate of extra-cytoplasmic activity, i.e. of enzymes on the plasma membrane (with active sites disposed toward the medium) plus enzymes external to the plasma membrane (Arnold, 1981). In the case of $S$. schenckii yeast cells the extra-cytoplasmic activity is reasonably equated with two of the Gomori-positive sites in micrographs (Garrison \& Arnold, 1983), namely the periplasm and the microfibrillar zone.

Mechanical disruption of $S$. schenckii yeast cells results in an increase in acid phosphatase activity of 50-75\% (Arnold et al., 1986; this paper); the increment is due to the exposure of the cytoplasmic enzymes to substrate and can be equated with vacuolar and internal membrane sites (Garrison \& Arnold, 1983).

\section{Kinetic parameters for intact cells}

The hydrolysis of $p$-nitrophenyl phosphate by cell suspensions followed Michaelis kinetics. The $K_{\mathrm{m}}$ value for this substrate in the presence of $0.2 \mathrm{M}$-acetate buffer ( $\mathrm{pH} \mathrm{5.0)}$ was determined 


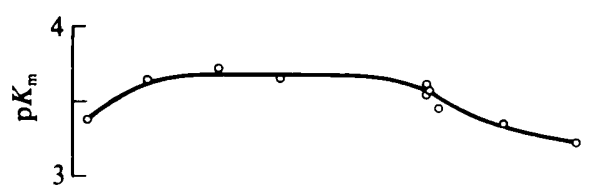

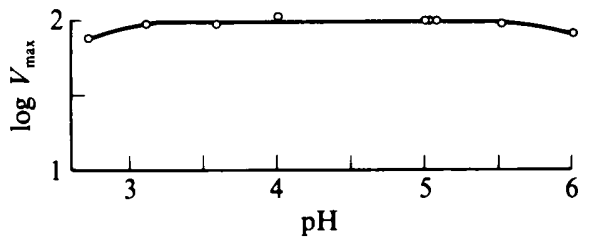

Fig. 1

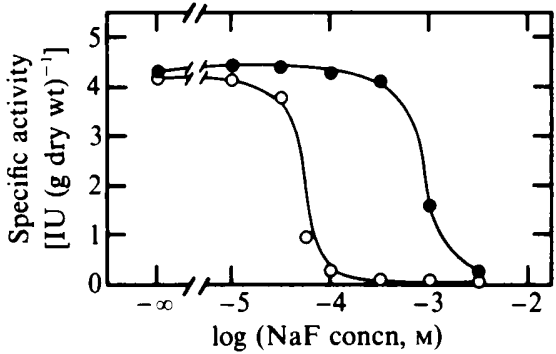

Fig. 2

Fig. 1. Effect of $\mathrm{pH}$. The Michaelis constant $\left(K_{\mathrm{m}}\right)$ and the maximum velocity $\left(V_{\max }\right)$ were determined over a range of $\mathrm{pH}$ values with $p$-nitrophenyl phosphate as substrate. $\mathrm{p} K_{\mathrm{m}}=-\log K_{\mathrm{m}}$.

Fig. 2. Inhibition by $\mathrm{NaF}$ and protection by citrate. Yeast cells were assayed for acid phosphatase at $30^{\circ} \mathrm{C}$ and $\mathrm{pH} 5.0$ in the presence of a range of $\mathrm{NaF}$ concentrations, in the presence $(O)$ and absence $(\mathrm{O})$ of $80 \mathrm{~mm}$-citrate.

\section{Table 1. Reversible inhibition by phosphate}

Cell suspensions were incubated for $30 \mathrm{~min}$ at $30^{\circ} \mathrm{C}$ in $0.2 \mathrm{M}$-acetate buffer (pH 5.0) and 20 mM-sodium phosphate as indicated. Acid phosphatase activities were then determined with $p$-nitrophenyl phosphate $(1.6 \mathrm{mM})$. The washing and resuspension medium was $0.2 \mathrm{M}$-acetate buffer (pH 5.0).

$\begin{array}{llc}\text { Addition } & \text { Post-treatment } & \begin{array}{c}\text { Specific activity } \\ \text { [IU (g dry wt) }\end{array} \\ \text { None } & \text { None } & 3.79 \\ \text { Phosphate } & \text { None } & 1.13 \\ \text { Phosphate } & \text { Washed once } & 3.68 \\ \text { Phosphate } & \text { Washed twice } & 3.86\end{array}$

on several batches of yeast : the mean value was $0.29 \pm 0.02 \mathrm{mM}(n=7)$. The effects of $\mathrm{pH}$ on $K_{\mathrm{m}}$ and $V_{\max }$ are summarized in Fig. 1 where the $\mathrm{pH}$ values refer to complete assay mixtures, the buffer in this case being $0.2 \mathrm{M}$ sodium acetate $/ \mathrm{HCl}$. There was less than $12 \%$ change in $V_{\max }$ between $\mathrm{pH} 3.0$ and 5.5. The $K_{\mathrm{m}}$ value was insensitive to $\mathrm{pH}$ between $\mathrm{pH} 3.0$ and 5.0 but increased outside that range. Dixon (1953) plots for the data of Fig. 1 were not easily interpreted because less than unit slopes were observed in the regions of change. There was some indication for the participation of two ionizable groups in the enzyme, one with a $\mathrm{p} K$ value of $<3$, and the other with a $K K$ between 5 and $5 \cdot 5$, and for a group in the enzyme-substrate complex with a $\mathrm{p} K$ between 5 and 6 (cf. the $\mathrm{p} K_{2}$ value for $p$-nitrophenyl phosphate which is approximately $5 \cdot 7$ ). The closeness of the projected $\mathrm{p} K$ values in the region 5 to 6 may explain the non-ideal curves.

\section{Inhibition by phosphate}

Sodium orthophosphate was a mild inhibitor of the acid phosphatase activity expressed by intact cells. Phosphate functions as a competitive inhibitor of $p$-nitrophenyl phosphate hydrolysis; the $K_{\mathrm{i}}$, based on velocity measurements at $\mathrm{pH} 5.0$ and substrate concentrations between 0.5 and $5.0 \mathrm{mM}$, with and without $10 \mathrm{~mm}$-sodium phosphate, was approximately $2 \mathrm{~mm}$. This inhibition was completely reversed by washing the cells (Table 1).

\section{Lack of tartrate inhibition}

$\mathrm{L}(+)$-Tartaric acid is a stereospecific inhibitor of some of the isoenzymes; however, at $40 \mathrm{~mm}$ it did not inhibit significantly the acid phosphatase of intact yeast cells. This concentration 


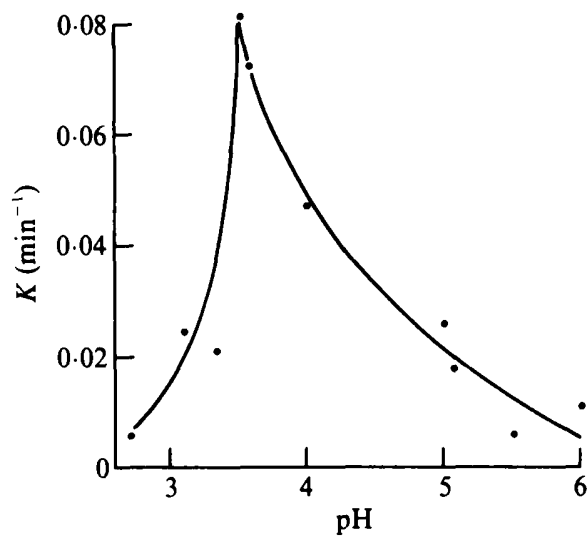

Fig. 3

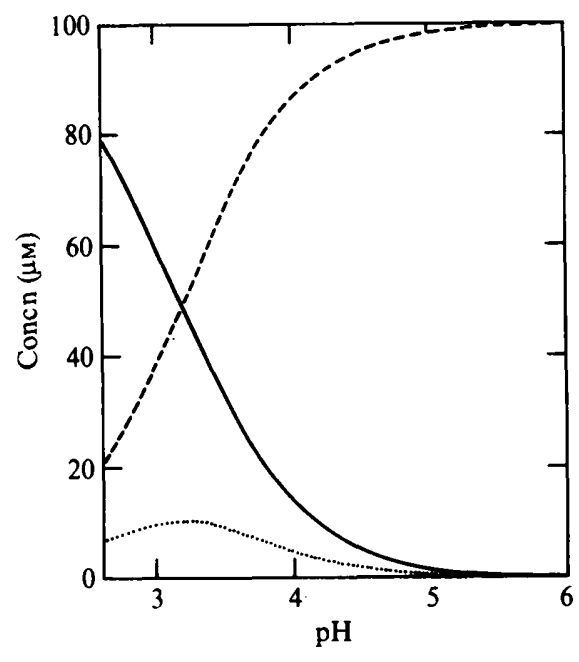

Fig. 4

Fig. 3. Effect of $\mathrm{pH}$ on the first order rate constant $(K)$ for inactivation by NaF. Values of $K$ were determined from plots of the natural logarithm of initial enzyme activity/residual activity after time $t$, against $t$ (not shown).

Fig. 4. Effect of $\mathrm{pH}$ on the concentration of fluorine species in aqueous $\mathrm{NaF}(0 \cdot 1 \mathrm{mM})$ at $30^{\circ} \mathrm{C}^{----}, \mathrm{F}^{-}$; $\longrightarrow, \mathrm{HF} ; \cdots, \mathrm{HF}_{2}^{-}$(note that the scale for $\mathrm{HF}_{2}^{-}$is $\times 1000$ ).

\section{Table 2. Inhibition by fluoride}

Yeast cells were assayed for acid phosphatase in the presence of $1.6 \mathrm{~mm}$-p-nitrophenyl phosphate in $0.2 \mathrm{M}$-acetate buffer ( $\mathrm{pH} 5.0$ ), and with $\mathrm{NaF}$ addition as indicated. The concentration of $\mathrm{NaF}$ was $50 \mu \mathrm{M}$ during the treatment and $30 \mu \mathrm{M}$ during the $10 \mathrm{~min}$ enzyme activity assay.

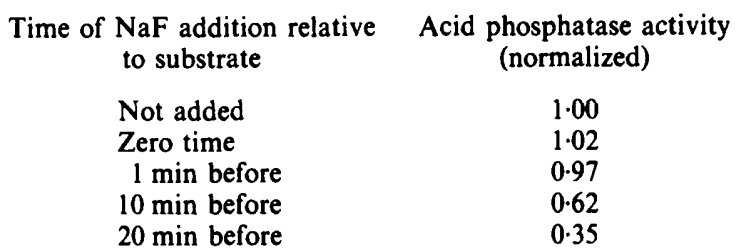

elicited only $3 \%$ lowering of the rate of $p$-nitrophenyl phosphate hydrolysis at pH $5 \cdot 0$, whereas sodium phosphate $(40 \mathrm{mM})$ and $\mathrm{NaF}(2 \mathrm{~mm})$ caused 66 and $95 \%$ decrease respectively under the same conditions.

\section{Inhibition by fluoride}

Preliminary trials revealed that phosphate, citrate and substrate can protect against inhibition by $\mathrm{NaF}$. The latter effect is demonstrated by the results of Table 2; inactivation followed first order kinetics. The protective effect by citrate on $\mathrm{NaF}$ inactivation is clearly demonstrated by the data of Fig. 2: $0.84 \mathrm{~mm}-\mathrm{NaF}$ was required for $50 \%$ inactivation in the presence of $80 \mathrm{~mm}$-citrate compared with only $0.05 \mathrm{mM}-\mathrm{NaF}$ for the same response in the absence of citrate. Inactivation by $\mathrm{NaF}$ was essentially irreversible: cells that had suffered 96$98 \%$ inactivation of extra-cytoplasmic acid phosphatase activity had an apparent recovery of only $4-9 \%$ with up to three succesive washes in acetate or citrate buffers respectively.

We also studied the effect of $\mathrm{pH}$ : in every case the inactivation by $0.1 \mathrm{~mm}-\mathrm{NaF}$ followed first order kinetics. Rate constants were plotted against pH (Fig. 3) and showed a steady increase from $\mathrm{pH} 6$ to $\mathrm{pH} 3 \cdot 5$, and then a precipitous decrease (i.e. the enzyme was less susceptible to 
inactivation). Controls indicated that the enzyme was not significantly inactivated by buffer alone over the $\mathrm{pH}$ range discussed.

An aqueous solution of $\mathrm{NaF}$ contains $\mathrm{HF}, \mathrm{F}^{-}, \mathrm{HF}_{2}^{-}$and $\mathrm{Na}^{+}$in concentrations that are governed by $\mathrm{pH}$ and the total concentration of added salt. The following relationships (Broene \& DeVries, 1947) apply to our conditions.

$$
\begin{array}{ll}
\mathrm{HF}=\mathrm{H}^{+}+\mathrm{F}^{-} & K=10^{-3 \cdot 2} \\
\mathrm{HF}+\mathrm{F}^{-}=\mathrm{HF}_{2}^{-} & K=4 \cdot 1 \\
{[\mathrm{HF}]+\left[\mathrm{F}^{-}\right]+\left[\mathrm{HF}_{2}^{-}\right]=100 \mu \mathrm{M}} &
\end{array}
$$

The concentrations of all species were calculated for any $\mathrm{pH}$ value by using molar concentrations throughout and were used to construct the curves of Fig. 4. It is apparent that the concentration of $\mathrm{HF}_{2}^{-}$(note the different scale) is always low. At the maximum, corresponding to the $\mathrm{p} K$ of $\mathrm{HF}$, the concentration of the dimer is $10 \mathrm{nM}$ compared with $50 \mu \mathrm{M}$ each of $\mathrm{HF}$ and $\mathrm{F}^{-}$. Consequently other investigators, under similar conditions but for other enzymes (Dunford \& Alberty, 1967; Segal et al., 1968) have ignored $\mathrm{HF}_{2}^{-}$. Reiner et al. (1955) claimed that $\mathrm{HF}_{2}^{-}$is the most important species participating in the reversible inactivation of prostatic acid phosphatase. That contention is not supported here, the only similarity being the biphasic nature for inactivation constant versus $\mathrm{pH}$ (Fig. 3). If a single fluorine-containing species were responsible the ratio of the inactivation rate constant to the concentration of that species would be invariant with $\mathrm{pH}$. This was not found for any of the three species. The simplest working hypothesis at present is that both $\mathrm{HF}$ and $\mathrm{F}^{-}$participate in the mechanism, and that the abrupt lowering in sensitivity below pH 3.5 may be explained by protonation of a critical amino acid side chain followed by a conformational change in the protein that affords protection from inactivation. Protonation alone is probably insufficient explanation because of the steepness of the curve below pH $3 \cdot 5$.

\section{Selective inactivation with fluoride}

It has been shown for higher plants (Peters et al., 1965) and baker's yeast (Rothman \& Cabib, 1966) that $\mathrm{NaF}$ is not toxic at $\mathrm{pH}$ values above 6.2 because $\mathrm{F}^{-}$(more than $99.9 \%$ of the total at these $\mathrm{pH}$ values) does not penetrate the plasma membrane (Simon \& Beevers, 1952). From the work of Arnold \& Lacy (1977) it is clear that anions in general are not freely admitted by yeast plasma membranes in the absence of a metabolizable substrate. These properties, taken together with the irreversibility of inactivation by fluoride in the present case, suggested the following locational studies.

A $20 \%(\mathrm{w} / \mathrm{v})$ suspension of yeast cells on $0.25 \mathrm{M}$-acetate buffer ( $\mathrm{pH} 6.5)$ was divided into two samples. $\mathrm{NaF}$ (final concentration $1.125 \mathrm{mM}$ ) was added to one sample only and both were then kept at $30^{\circ} \mathrm{C}$ for $30 \mathrm{~min}$ before washing in the same buffer. Yeast cells were not killed by these pretreatments as indicated by methylene blue exclusion and viability counts on agar plates. Samples were assayed for acid phosphatase activity and the remainder in each case was disrupted in a French pressure cell. Further assays on broken cells and derivative fractions, with and without inhibitors, completed the study summarized in Table 3. A completely independent experiment with another batch of yeast yielded similar results (Table 3). The irreversibility of the $\mathrm{NaF}$ treament permitted washing away of excess inhibitor before cell disruption so that the newly exposed enzyme could be assayed in the absence or presence of $\mathrm{NaF}$ and other inhibitors.

The $\mathrm{NaF}$ pretreatment of intact cells irreversibly inactivated $90-94 \%$ of the extracytoplasmic acid phosphatase activity yet the same cells retained active cytoplasmic acid phosphatase (Table 3). The cytoplasmic activities (increments after cell breakage) were about $80 \%$ of those observed for untreated cells and they were also susceptible to inhibition by fluoride. These data indicate a selective effect of fluoride on intact cells, under the specified conditions.

A small but consistent fraction (3-5\% of the total) in both sediments and supernatants resisted inhibition by $2 \mathrm{mM}-\mathrm{NaF}$ and, for the supernatants at least, may correspond to isoenzymes $\mathrm{Y}$-II $d$, Y-II $e$ and Y-V (Arnold et al., 1986) which are known to be resistant. It is worth noting that the 
Table 3. Inactivation of the extra-cytoplasmic fraction

Details of the NaF pretreatment and mechanical disruption are given in the text. Values in parentheses were from an independent experiment with another batch of yeast.

\begin{tabular}{|c|c|c|}
\hline \multirow[b]{2}{*}{ Sample } & \multicolumn{2}{|c|}{ Acid phosphatase [IU (g dry wt $\left.)^{-1}\right]$} \\
\hline & Control & NaF-pretreated \\
\hline Cells & $5.67(4.92)$ & $0.56(0.28)$ \\
\hline Broken cells & $8.76(8.51)$ & $3.00(3 \cdot 18)$ \\
\hline Increment due to breakage & $3.09(3.59)$ & $2.44(2.90)$ \\
\hline Supernatant fraction & $2 \cdot 11(2 \cdot 51)$ & $1 \cdot 19(1.59)$ \\
\hline Supernatant $+\mathrm{NaF}(2 \mathrm{mM})$ & $0.42(0.60)$ & $0.49(0.67)$ \\
\hline Supernatant + phosphate $(40 \mathrm{~mm})$ & $1.05(0.88)$ & $0.71(1.03)$ \\
\hline Supernatant $+\mathrm{L}(+)$-tartrate $(40 \mathrm{~mm})$ & $1.69(2.04)$ & $0.81(1.09)$ \\
\hline Sediment & 4.97 & 1.43 \\
\hline Sediment $+\mathrm{NaF}$ & $0 \cdot 27$ & $0 \cdot 28$ \\
\hline Sediment + phosphate & $2 \cdot 27$ & 0.66 \\
\hline Sediment + tartrate & 4.67 & $1 \cdot 16$ \\
\hline
\end{tabular}

cytoplasmic fraction is to some extent susceptible to inactivation by phosphate and $\mathrm{L}(+)-$ tartrate (Table 3) (Arnold et al., 1986). A significant fraction of the total activity in broken cells was sedimented by centrifugation at $20200 \mathrm{~g}$ for $20 \mathrm{~min}$; this fraction has been equated with broken cell walls and various cytoplasmic membranes and particles (Arnold et al., 1986). Present results together with those from unpublished trials indicate that the activity of debris is consistently about $85 \%$ of that for intact cells. Cytochemical findings (Garrison \& Arnold, 1983) indicated that much of this insoluble activity may be associated with microfibrillar material. On the other hand, a cytoplasmic contribution is apparent from the analyses of untreated cells and is further supported by analysis of the NaF-treated cells (Table 3 ), wherein a 2.5-fold increase in the activity of the sediment from broken cells over that for intact cells was noted.

Cell-free extracts were examined by gel electrophoresis and enzyme staining. The isoenzyme most affected by NaF pretreatment of intact cells was Y-I, which is evidently a constituent of the extra-cytoplasmic fraction. This is in keeping with the results of many previous analyses on crude extracts in that $\mathrm{Y}-\mathrm{I}$ was strongly inhibited by $\mathrm{NaF}$, mildly inhibited by phosphate, and not inhibited by $L(+)$-tartrate, i.e. the same pattern of inhibition reported above for the extracytoplasmic fraction of intact yeast cells. Only $6-10 \%$ of the extra-cytoplasmic fractions survived the $\mathrm{NaF}$ pretreatment (Table 3), but scanning densitometer analysis of gels indicated about $40 \%$ remaining in the treated extract compared with the control. A possible explanation is that there is also some Y-I isoenzyme in the cytoplasm.

Isoenzyme Y-I barely enters the gel in the present system of electrophoresis. We do not consider that this activity is associated with particles (Arnold et al., 1986); however, it could be due to a large native molecular mass to self-aggregation, or to association with other polymers in the crude extract. A limited number of trials with detergents and higher porosity gels have not yet afforded increased electrophoretic mobility but further attempts are being made.

Interest in isoenzyme Y-I is sharpened by the possibility that it is associated with the microfibrillar zone of yeast cells, which would certainly allow direct interaction of this enzyme of the pathogenic cells with macrophages and other host cells. The interaction of $S$. schenckii yeast cells with human neutrophils is under current investigation. In this general context, Remaley et al. (1984) claim a direct interaction of an acid phosphatase on the surface of the protozoan Leishmania donovani with host macrophages.

We thank Drs Robert Garrison, Archie Murdock and Dan Carr for helpful discussions. The work was supported by US Public Health Service Grant AI20761 to W.N.A.

\section{REFERENCES}

ARNOLD, W. N. (1981). Enzymes. In Yeast Cell Envelopes: Biochemistry, Biophysics, and Ultrastructure, vol. II, pp. 1-46. Edited by W. N. Arnold. Boca Raton, Florida: CRC Press.
ARnold, W. N. \& LACY, J. S. (1977). Permeability of the cell envelope and osmotic behavior in Saccharomyces cerevisiae. Journal of Bacteriology 131, 564571 . 
Arnold, W. N., ManN, L. C., Sakai, K. H., Garrison, R. G. \& Coleman, P. D. (1986). Acid phosphatases of Sporothrix schenckii. Journal of General Microbiology 132, 3421-3432.

Broene, H. H. \& DeVries, T. (1947). The thermodynamics of aqueous hydrofluoric acid solutions. Journal of the American Chemical Society 69, 1644 1646.

DAVIS, B. J. \& ORNSTEIN, L. (1959). High resolution enzyme localization with a new diazo reagent, 'hexazonium paparosaniline'. Journal of Histochemistry and Cytochemistry 7, 297-298.

Dixon, M. (1953). The effect of pH on the affinities of enzymes for substrates and inhibitors. Biochemical Journal 55, 161-170.

DUNFORD, H. B. \& AlberTy, R. A. (1967). The kinetics of fluoride binding by ferric horseradish peroxidase. Biochemistry 6, 447-451.

Garrison, R. G. \& ARnold, W. N. (1983). Cytochemical localization of acid phosphatases in the dimorphic fungus Sporothrix schenckii. Current Microbiology 9, 253-258.

GOMORI, G. (1950). An improved histochemical technique for acid phosphatase. Stain Technology 25, 81-85.

IVETT, R. \& DeVRIES, T. (1941). The lead amalgamlead fluoride electrode and thermodynamic proper- ties of aqueous sodium fluoride solutions. Journal of the American Chemical Society 63, 2821-2825.

Peters, R. A., Murray, L. R. \& Shorthouse, M. (1965). Fluoride metabolism in Acacia georginae Gidyea. Biochemical Journal 95, 724-730.

Reiner, J. M., Tsuboi, K. K. \& Hudson, P. B. (1955). Acid phosphatase. IV. Fluoride inhibition of prostatic acid phosphatase. Archives of Biochemistry and Biophysics 56, 165-183.

Remaley, A. T., Kuhns, D. B., Basford, R. E., Glen, R. H. \& KaPLAN, S. S. (1984). Leishmanial phosphatase blocks neutrophil $\mathrm{O}_{2}^{-}$production. Journal of Biological Chemistry 259, 11173-11175.

RothmaN, L. B. \& CABIB, E. (1966). Inhibition of yeast growth by fluoride and its reversal by phosphoric esters: an effect of $\mathrm{pH}$. Biochimica et biophysica acta $117,482-485$.

Segal, R., Dunford, H. B. \& Morrison, M. (1968). The kinetics of fluoride binding by lactoperoxidase. Canadian Journal of Biochemistry 46, 1471-1474.

Simon, E. W. \& BeEvers, H. (1952). The effect of pH on the biological activities of weak acids and bases. I. The most usual relationship between $\mathrm{pH}$ and activity. New Phytologist 51, 163-190.

Travassos, L. R. \& LlOYD, K. O. (1980). Sporothrix schenckii and related species of Ceratocystis. Microbiological Reviews 44, 683-721. 